\title{
Design and Implementation of Higher Vocational English Writing and Training Testing System
}

\author{
LI Liang ${ }^{1, a}$ \\ ${ }^{1}$ Foreign Language School, Wuhan Polytechnic,Wuhan 430074, P.R China \\ aliliang109@126.com
}

Keywords: Higher Vocational School; English Wring; Testing System; Training

\begin{abstract}
English writing is the main tool for testing vocational colleges students' English ability to learn and use English, which is also an important reference index to test students' English practical application ability. In order to enhance the level of higher vocational college students' English writing ability and cater to the demands of higher vocational colleges to cultivate the students' flexible application of technology and realize development of their own, intelligent WEB based English writing test platform arises at the historic moment.
\end{abstract}

\section{Relevant concepts}

\section{Higher vocational colleges}

This article talks about higher vocational colleges, which is different from colleges and universities. Higher vocational colleges directional system is three years or five years, which are sent up for cultivating talents with strong practical ability. If learn skills used correctly when in school, students can mount guard hired directly after graduation. This kind of colleges and universities keeps the principle of "enough is fine, practical is the direction", the purpose of students' learning is very clear that is to learn something enough to work. In On strengthening the vocational education personnel training work opinion, the ministry of education pointed out that higher vocational education to cultivate higher technology applied special talents tat support the party's basic line, adapt to the production, construction, management and service first line need. [1]

\section{Vocational college English teaching}

English teaching in higher vocational colleges is also different from other professional teaching. Colleges and universities pay attention to the accumulation of learning. The aim of languange learning to use it, but students in real teaching situation seldom consciously use English in daily communication. The result is that most people learn English for decades, but incapable of basic daily conversation, not to mention the use of language to do things.

In order to avoid such defects in higher vocational colleges, training class is opened and task-based teaching method is adopted. At home, Jiangxi province has comparatively more vocational colleges. Take Jiangxi foreign language foreign trade vocational college as an example, it was founded in 1964, although its time is not long, but the school began to implement task-based teaching method very early, the traditional 3 p teaching method have been eliminated. This kind of teaching method is not only suitable for business English majors, it also applies for non-English majors, and is suitable for different class type, such as reading class lesson, oral, listening and writing.

\section{Teaching method}

The concept of teaching everyone is not unfamiliar, but in terms of definition, there is many confusion. Because teaching method refers to the teaching concept, teaching skills, or the teacher own teaching style. In abroad, scholars of translation have different views of teaching, some think it is it should be Approach, while some think it should be Method. In fact the two are not separate parts of speech, instead, it encompasses the relationship. However, Approach cannot beyond some advantage of Method. Such as the Approach of the disadvantage failed to tell the application of teachers' teaching, teachers can only use Approach expertise be based on personal understanding and personal. The advantages of the Method lies in the strong "guidance". The solution is according 
to the teaching method and teaching content so teaching activities becomes rich[2].

\section{Current situation of higher vocational English teaching and existing problems}

Higher vocational education attaches great importance to higher education that of knowledge as the characteristics of the form of in recent years under the support of national policy, has been in rapid development. As a foundation in the higher vocational education branch, the higher vocational English education also get the attention of more and more relevant scholars and educators.

\section{From the aspect of students}

Based on researches, the author summarizes the following characteristics and status quo of higher vocational students' current English learning:

1) English basic level differs

Students of higher vocational students are of greater flexibility, the selection of teaching materials are different, so the basic English level difference is large. More obviously, the Shanghai students command better English than from students from outside. As a result, the student basic English foundation can be divided into many levels. In the class, there will be some people can learn more while there are also students that cannot understand the class well. What makes it worse is that during the period of in high school or vocational education, higher vocational students pay little importance to basic literacy class learning, some even ignore the basic academic system training or resist, so that the whole system theory and abstract thinking ability are relatively weak, language training this relatively boring project is interest and ability is not enough.

2) Lack learning motivation

English learning motivation is internal psychological initiative to stimulate students English learning activities, maintain English learning activities, and the keep behavior towards an inner process of English learning goals. [3]Research shows that higher vocational students of English learning motivation is not strong. The survey found that $35.43 \%$ of the students learn English in order to cope with exams have diploma, $58.60 \%$ of the students are to have level foreign language level certificate in order to have a better development opportunity in the future work and career, only $2.37 \%$ of the students because English is very interesting, want to learn some more. Because more than $97 \%$ of the students take no initiative to learn but because of social pressure and in learning this course, it inevitably leads to the inefficiency of English class teaching. Learning interest is the most realistic and the most active factors in the learning motivation, which is the forerunner of self-study learning, the main source of motivation.

\section{From the aspect of teachers}

1) Obsolete teaching idea and low theory quality

Because of heavy teaching task, study the atmosphere at vocational school is not strong, therefore, a lot of higher vocational English teachers lack of systematic study and update in the teaching of theory. Higher vocational English teachers' theory quality remains to be improved. The lack of the guidance of theories make teaching have no direction; lack of design and reflection, the reform of higher vocational English teaching and optimization is more difficult.

2) Single teaching means and old teaching methods

Although there have been some transformation of teaching methods in the higher vocational teachers, but most of the higher vocational English teachers in English class carry on the past "cramming education" teaching methods, in which condition teaching is the main means of teaching. Teacher's explanation account for more than $80 \%$ of the time in the class, students almost passively accept, learning initiative, enthusiasm and creativity are curbed, enthusiasm to participate in the activities of classroom teaching is not high, which is not conducive to the improvement of students' language communicative competence.

3) The students' classroom participation is not high, inside and outside the classroom interaction

Now many higher vocational schools are more focused on cultivating skilled and practical talents, increase the school leader of professional course of development, and began to compress such basic course of English class. Therefore, higher vocational English teachers is to catch up, many teachers think classroom interaction is time, not fast as direct teaching, thus the interactions 
between teachers and students as well as living in the English classroom is even more rare, most take big class teaching of higher vocational English class, the students' participation is very low[4].

\section{Demand research and analysis of architecture system}

\section{Analysis of requirements to form a system}

With the continuous development of computer network, the original writing and testing training model cannot meet the needs of large-scale student online English learning and testing, and we also won't correcting the students' English test operation using a traditional way to print like before but use fast network online learning. This make resources of English writing for students and test becomes rather important, research and development of writing start from the test system based on this point.

\section{Analysis of system function module}

Through analyzing the teaching of teachers and students in the actual, this system can meet the demand of teachers and students English writing online training and testing, which also can be used as one of platform for students self-study and test at home of their learning.

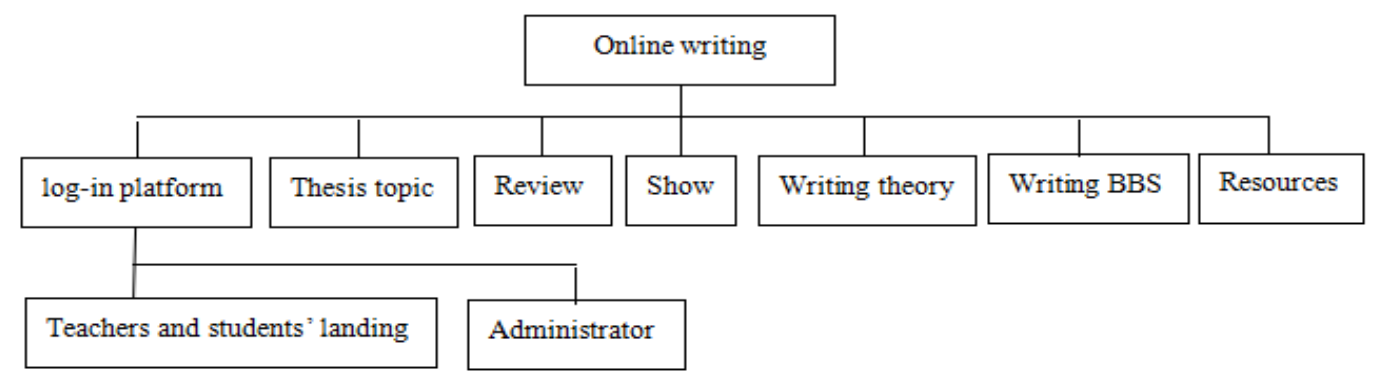

Figure 1.System online writing function module structure diagram

\section{Analysis of hardware and software performance}

(1) The hardware environment

Processor: Intel Pentium dual-core CPU E7200 or higher

Memory: 2G

Hard disk space: 1 TB

Graphics: VGA or higher resolution of the monitor

All kinds of monochrome and color display Windows support .

(2) The software environment

Operating system: Windows 2000 / XP/Vista/Windows 7

Database: SQL Server 2010

The front desk development interface: MyEclipse 8.5

\section{Fitness function design}

Suppose composite service $s$ is composed of $n$ tasks, $\left\{t_{1}, t_{2}, \ldots, t_{n}\right\}$, and service QoS is described by $m$ QoS attributes, namely $\left\{Q_{1}, Q_{2}, \ldots, Q_{m}\right\}$. According to the QoS computation model, we obtain the calculating formula of the individual objective function $f$ :

$f=\sum_{i=1}^{m}\left(\omega_{i} \times Q_{i}\right)$

The final composite service $f$ evaluation function $\mathrm{f}$ can be expressed as:

$$
f=\sum_{i=1}^{m}\left(\omega_{i} \times Q_{i}^{\prime}\right)
$$

In the above formula, $\sum_{i=1}^{m} \omega_{i}=1,0 \leq \omega_{i} \leq 1,0 \leq Q_{i}^{\prime} \leq 1$.

\section{Analysis system feasibility}

With the continuous development of education technology, the popularity of campus network, 
the concept of digital campus is accepted more and more by people. Digital campus is to widely use network, computer and multimedia for the integration of information technology in the college. It is a digital revolution of the traditional writing instruction and test model. This system use this mature network technology to computer technology application in the teaching management achieve great progress, which not only improve the capabilities of the students' English writing, such as the ability to use advanced information technology to obtain information, analyze information, the ability to process information, but also improve the level of the teaching management in colleges and universities.

\section{Comprehensive planning and design of system}

This system is divided into writing online function module and online testing function modules. The function of module design is specifically introduced below.

\section{Online writing function module}

Writing teaching mode based on Network technology ASP.NET is of teachers and students, PC terminal, operating system, Internet, etc. five parts. Through this kind of writing and test mode, the teachers and students need to master basic network knowledge and skilled computer operation. Therefore, higher vocational colleges online writing center frame contains the following components: online writing lab; resources; Interaction and feedback; file cover; related links; the campus data; teachers writing tutoring; online practice and test; the campus BBS communication; learning files; students study; corpus and so on.

\section{Online examination function module}

System test function module mainly includes the landing module, test module, check module, the text management module, students management module, grade management module. System function module is as shown in figure below:

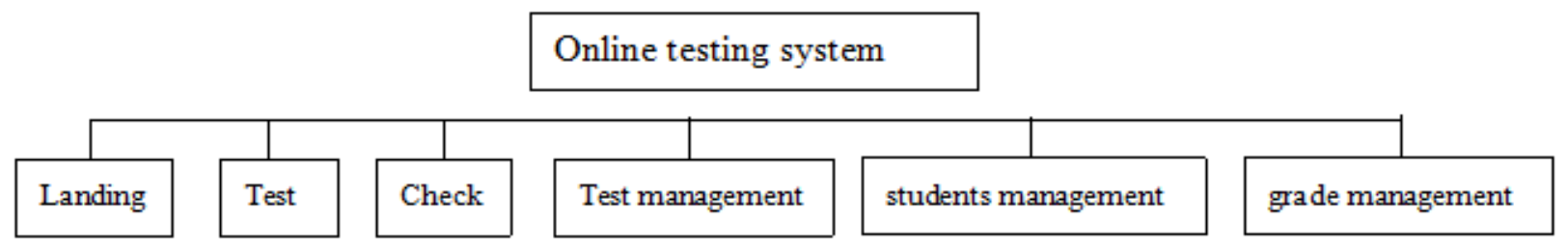

Figure 2. System function module

\section{Design of database analysis}

In this system, we need the following table to store the data:

(1) student information table, including student id, real name, password, age, professional, class, home, mobile phone number, QQ, Email;

(2) information of choice : number choice questions, questions, answer A and answer B, answer, answer D C, the correct answer, score;

(3) question information table: question number, questions, answers, scores;

(4) temporary table of answer : student id, subject type, number, answer;

(5) student achievement: student id, score, pass the state and number;

(6) feedback: Numbers, pet name, Email, content.

\section{Summary}

It has become one of the trend of the education development today that take online long-distance as the main means in higher vocational colleges. Both at home and abroad, online long-distance education are in vigorous development mode. Online education in both Chinese and English writing and test question bank system is a core foundation part of distance education. So, take the traditional education resources in English teaching at home and abroad for reference, integrate the original traditional teaching method and modern education to test the new model, English writing and testing system based on Web of research are all very important for the 
development of modern education mode.

\section{References}

[1] Dam L. Learner Autonomy: From Theory to Classroom Practice[M], Dublin: Authentic, 1995:31.

[2] Xu, Libin. 1993. A Sun^ey of College English Writing Instruction in China and Suggestions for Improvement. Dissertation, West Virginia University.

[3] Yu, Chen-Chung. 1984. Cultural principles underlying English teaching in China [J].

[4] Language Learning and Communication, 3: 29-40. Zamel, V. 1976. Teaching composition in the ESL classroom: What we can learn from research in the teaching of English [J]. TESOL Quarterly,10: 67-76. 